\title{
Peningkatan Pengetahuan dan Motivasi Kader Posyandu di Bojong Menteng Melalui Webinar Gizi Saat Pandemi COVID-19
}

\author{
Lina Agestika ${ }^{1}$, Angga Rizqiawan ${ }^{1}$, Mita Arini $^{1}$, Befi Sundari ${ }^{1}$, Hassya Maulida Nugraha ${ }^{1}$, Khalissa \\ Fathin Anshari ${ }^{1}$, Putri Ayu Mulya ${ }^{1}$, Ria Wati ${ }^{1}$ \\ ${ }^{1}$ Program Studi Gizi, Fakultas Ilmu Kesehatan dan Teknologi, Universitas Binawan \\ Email:lina.agestika@binawan.ac.id
}

\begin{abstract}
The disturbance in performing Poyandu routine activities in Puskesmas Bojong Menteng and faceto-face Cadre refresher during COVID-19 pandemic might reduce cadres' motivation and knowledge. A virtual education program through webinars is one of the possible solutions. This community service activity aims to analyze the effects of webinar on nutrition through zoom meeting on cadres' motivation and knowledge regarding 1) the role of cadres during the pandemic, 2) prevention of COVID-19 with balanced nutrition, water, sanitation, hygiene, and physical activity and 3) introduction to Ms. Excel application in smartphone. The webinars were given in 2 days with delivering a pre- and post-test evaluation. The statistical analysis used was Wilcoxon signed-rank test. Participants were 33 Cadres. Cadres have received technical guidance to use the zoom application on their smartphone prior to the webinar schedule. The majority of cadres are in the age of 31-45 years old (45.5\%) and have graduated from high school (63.6\%). Result shows that the mean of Cadre's score on knowledge and motivation had increased from 65 to 85 and 90 to 100 ( $p$ : <0.05). This concludes that webinars could be a potential way to refresh and educate Posyandu cadres during a pandemic.
\end{abstract}

Keywords: education, pandemic, posyandu, webinars, zoom

\begin{abstract}
Abstrak
Kader di wilayah kerja Puskesmas Bojong Menteng, mengalami tantangan dalam melaksanakan kegiatan Posyandu saat pandemi COVID-19, terutama dalam menyelenggarakan program penyegaran kader secara tatap muka. Terhambatnya kegiatan ini berisiko menurunkan pengetahua dan motivasi kader. Edukasi melalui webinar menjadi salah satu jenis aktivitas yang sesuai selama pandemi. Namun, pengaruhnya terhadap pengetahuan dan motivasi peserta masih jarang diketahui. Kegiatan pengabdian masyarakat ini bertujuan untuk mengevaluasi pengaruh penyuluhan dengan webinar online di zoom terhadap pengetahuan kader mengenai 1) Peranan kader Posyandu di masa pandemi, 2) Pencegahan COVID-19 dengan gizi seimbang, sanitasi, air bersih, kebiasaan cuci tangan dan beraktivitas fisik dan 3) Pengenalan aplikasi Ms. Excel di gawai pintar; dan motivasi kader. Evaluasi kegiatan dilakukan melalui pengisian pre- dan post-test. Analisis statistik yang digunakan adalah Wilcoxon signed rank test. Kader Poyandu yang berpartisipasi berjumlah 33 orang. Kader dibimbing untuk menggunakan aplikasi zoom di gawai pintar sebagai persiapan mengikuti acara webinar seminggu sebelum webinar. Mayoritas kader berada di rentang usia 31-45 tahun $(45.5 \%)$ dan memiliki tingkat pendidikan terakhir SMA (63.6\%). Nilai rata-rata pengetahuan dan motivasi kader sebelum dan sesudah acara webinar mengalami peningkatan yaitu 65 menjadi 85 dan 90 menjadi 100 ( $p$-value<0.05). Kesimpulannya, webinar dapat menjadi cara yang potensial dalam mengedukasi kader Posyandu selama pandemi.
\end{abstract}

Kata Kunci: edukasi, pandemi, posyandu, webinar, zoom

\section{PENDAHULUAN}

COVID-19 merupakan penyakit infeksi yang menular secara cepat dan mudah dari manusia ke manusia maupun melalui udara yang mengandung percikan (droplets) dari individu yang terinfeksi (WHO, 2020). Data global menunjukan bahwa 224 negara terkonfirmasi terjangkit 
COVID-19 dengan jumlah kasus positif mencapai 99 juta orang dan 2 juta orang meninggal (Komite Penanganan COVID-19 dan Pemulihan Ekonomi Naisonal, 2021). Indonesia sendiri terus mengalami peningkatan kasus dengan lebih dari 1 juta orang terdeteksi positif dengan 28 ribu orang meninggal. Oleh karena itu, Pemerintah mengeluarkan PP No. 21 tahun 2020 tentang penerapan PSBB atau pembatasan sosial berskala besar sebagai upaya untuk memutus rantai penularan virus tersebut (Presiden Republik Indonesia, 2020).

Jauh sebelum pandemi, Riset Kesehatan Dasar (RISKESDAS) tahun 2018 menunjukkan bahwa terdapat penurunan proporsi balita underweight $(19,6 \%$ menjadi $17,7 \%)$, stunting $(37,2 \%$ menjadi $30,8 \%$ ), dan overweight $(11,8 \%$ menjadi $8 \%$ ), namun hal tersebut masih dinilai kurang signifikan (Kementerian Kesehatan RI, 2018). Selain itu, ibu hamil yang anemia juga meningkat menjadi $48,9 \%$, namun yang secara rutin dan patuh mengkonsumsi tablet tambah darah hanya sebesar 73,2\% (Ministry of Health of Indonesia, 2018). Kondisi malnutrisi pada anak dapat memperburuk kondisi infeksi baik itu COVID-19 maupun infeksi lainnya (Fore et al., 2020). Sebaliknya, hal tersebut juga dapat memperburuk kondisi malnutrisi akibat tingkat keparahan, gangguan terhadap akses pangan dan pelayanan kesehatan (Fore et al., 2020). Ibu hamil juga merupakan populasi rentan yang memiliki resiko yang sama dengan orang dewasa lainnya untuk terinfeksi pneumonia (Yang et al., 2020). Dengan demikian, ibu dan balita membutuhkan perhatian khusus selama pandemi terutama karena terbatasnya proses penyelenggaraan pelayanan kesehatan.

Wilayah kerja Puskesmas Bojong Menteng merupakan fasilitas kesehatan yang menemui tantangan dalam menyelenggarakan pelayanan kesehatan di Kota Bekasi. Menurut laporan di tahun
2014, Puskesmas ini memiliki tingkat partisipasi yang rendah terhadap program penimbangan di Posyandu yang hanya mencapai $44,5 \%$, kasus TB yang mencapai $48,57 \%$, pneumonia $28,5 \%$, diare $70,29 \%$, obesitas 2,1\% dan gizi buruk 1,2\% (Dinkes Kota Bekasi, 2014). Wawancara awal dengan petugas Puskesmas di tahun 2020 memaparkan bahwa $16 \%$ balita di bawah garis kuning dan 2 orang di bawah garis merah serta 8 orang ibu hamil mengalami anemia. Fasilitas sanitasi yang masih tradisional dengan tidak menggunakan jamban juga dikemukakan masih ada di 5 RW dengan kualitas air minum yang kurang layak. Bojong menteng juga merupakan kelurahan dengan jumlah kasus penyebaran COVID-19 tertinggi ketiga di Kecamatan Rawa Lumbu dengan jumlah 822 kasus (Dinas Kesehatan Kota Bekasi, 2021). Masalah-masalah tersebut berpotensi dalam menyebabkan terjadinya penularan penyakit dan meningkatkan masalah gizi di masa yang akan datang.

Sebagai upaya pencegahan dan penanggulangan masalah ini, selain petugas kesehatan pada tingkat kecamatan dan kota, masyarakat membutuhkan perantara untuk mejalankan program di tingkat RT dan RW (Kemenkes RI, 2014). Keberadaan Posyandu sebagai pelayanan informasi kesehatan ibu dan anak dinilai sangat efektif sebagai wadah penyampaian informasi terkait kesehatan yang optimal untuk keluarga sehat. Berjalannya kegiatan di Posyandu ditentukan oleh motivasi dan kualitas pengetahuan dari para kader. Terlebih lagi dengan adanya pandemi, peralihan masa new normal membuat peran dan keaktifan dari kader terhambat akibat dihentikannya aktivitas Posyandu untuk sementara waktu karena PSBB.

Penelitian yang dilakukan oleh Kusudaryati et al., (2017) menunjukkan bahwa pemberian pendidikan dan buku gizi dapat meningkatkan pengetahuan kader tentang gizi balita. Hal tersebut juga didukung oleh penelitian yang dilakukan 
oleh Solehati et al., (2018) yang menunjukkan bahwa pelatihan tentang kesehatan berpengaruh dalam meningkatkan tingkat pengetahuan kader terkait deteksi dini dan pencegahan anemia. Terlebih lagi motivasi dan pengetahuan kader diharapkan tidak menurun meskipun dalam kondisi PSBB.

\section{TARGET DAN LUARAN}

Target pengabdian masyarakat ini adalah Kader Posyandu UPTD Puskesmas Bojong Menteng. Luaran yang diharapkan dalam pengabdian masyarakat ini adalah membentuk kader mandiri dan siaga yang dapat memberikan informasi terkait pentingnya peran kader Posyandu, isu gizi terkini, konsep dan prinsip gizi seimbang, pola makan sesuai dengan pedoman gizi seimbang, pentingnya aktivitas fisik dan air bersih, sanitasi dan hygiene untuk mencapai status gizi dan kesehatan yang optimal.

\section{METODE PELAKSANAAN}

Kegiatan pengabdian masyarakat ini dilaksanakan pada Kader Posyandu di wilayah kerja Puskesmas Bojong Menteng, Kota Bekasi pada 12 dan 19 Januari 2021. Seluruh kader dari 21 Posyandu menjadi peserta kegiatan penyuluhan secara sinkron maya. Program pengabdian masyarakat dilakukan dengan rincian sebagai berikut:

\section{Penyuluhan dengan Webinar Online}

Proses penyuluhan dilaksanakan sebanyak dua kali pertemuan yang diawali dengan proses pengenalan terhadap aplikasi zoom kepada para kader. Kader diberikan tautan pertemuan zoom seminggu sebelum dilaksanakannya webinar online. Seluruh peserta kegiatan dapat bergabung dengan menggunakan akun masing-masing atau berkelompok di satu Posyandu. Kamera dihidupkan selama webinar berlangsung. Acara webinar dilaksanakan selama 100 menit per pertemuan. Pemaparan dilakukan oleh tiga narasumber yang masing-masing diberikan waktu selama 15 hingga 20 menit melalui layar seperti Gambar 1.

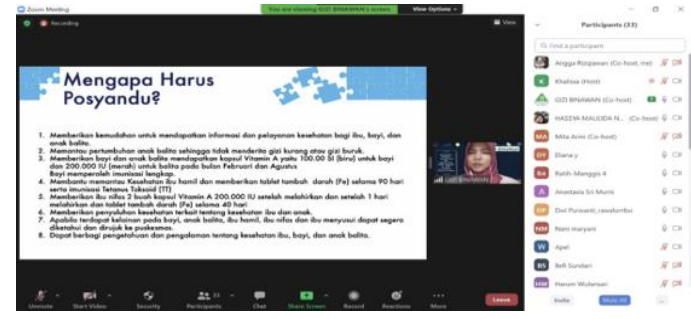

Gambar 1. Dokumentasi pemaparan materi oleh pembicara

\section{Tahapan Webinar}

Tahapan penyelenggaraan webinar yaitu pembukaan, pemberian pre-test sebelum dimulainya acara webinar, penyampaian materi oleh pembicara tanya jawab dan pengisian post-test setelah webinar selesai. Jumlah pertanyaan pada pre- dan post-test adalah 10 pertanyaan terkait dengan motivasi kader, peranan dan pelaksanaan kegiatan Posyandu pengetahuan terkait gizi seimbang, pengelolaan air, sanitasi dan hygiene dan alur penyebaran COVID-19

\section{Materi Penyuluhan}

Materi penyuluhan yang diberikan antara lain; 1). Peranan kader Posyandu di masa pandemi, 2). Pencegahan COVID-19 dengan gizi seimbang, sanitasi, air bersih, kebiasaan cuci tangan dan beraktivitas fisik, 3) Pengenalan aplikasi Ms. Excel di gawai pintar.

\section{Pengolahan Data}

Pengolahan data dilakukan melalui dua analisis. Pertama, analisis univariat untuk mengetahui proporsi dari beberapa variable dan mengetahui sebaran data normal. Kedua, analisis bivariat dengan menggunakan Wilcoxon signed rank test.

\section{HASIL DAN PEMBAHASAN}

Posyandu sebagai pusat pelayanan kesehatan ibu dan anak dinilai sangat efektif sebagai wadah penyampaian informasi terkait kesehatan yang optimal untuk membangun keluarga sehat. Kader merupakan pionir yang menjadi perantara terlaksananya program-program pemerintah untuk mengoptimalkan masyarakat sehat. 
Kader biasanya adalah masyarakat umum dengan latar belakang pendidikan yang berbeda-beda dan bahkan seringkali tidak mumpuni yang bekerja secara sukarela di Posyandu (Agus Susanto, 2017; Lubis, 2015; Solehati et al., 2018). Hal tersebut menjadikan penyuluhan tentang kesehatan dan gizi bagi kader posyandu menjadi penting dilakukan. Dilatarbelakangi mengingkatnya penyebaran kasus COVID19 di Bekasi, maka kegiatan pengabdian kepada masyarakat dilaksanakan secara sinkron maya menggunakan aplikasi zoom. Tabel 1. Karakteristik responden

\begin{tabular}{lc}
\hline \multicolumn{1}{c}{ Karakteristik } & $\mathrm{n}(\%)$ \\
\hline Usia & $6(18.2)$ \\
20-30 tahun & $15(45.5)$ \\
31-45 tahun & $12(36.3)$ \\
46-60 tahun & $0(0)$ \\
>60 tahun & \\
Tingkat Pendidikan & $0(0)$ \\
Tidak sekolah & $0(0)$ \\
SD & $7(21.2)$ \\
SMP & $21(63.6)$ \\
SMA/SMK & $5(15.2)$ \\
Perguruan Tinggi &
\end{tabular}

Tabel 1 merupakan gambaran karakteristik peserta webinar. Jumlah kader yang berpartisipasi dalam kegiatan ini berjumlah 33 orang. Mayoritas dari peserta berada di rentang usia 31-45 tahun (45.5\%). Sementara itu, berdasarkan tingkat Pendidikan, sebagian besar dari peserta memiliki tingkat pendidikan SMA/SMK (63.6\%). Hasil tersebut sesuai dengan penelitian Hardiyanti et al. (2018) yang menyatakan mayoritas kader tingkat pendidikannya adalah SMP/SMA.

Tingkat pendidikan memiliki pengaruh terhadap kinerja kader, contohnya pada akurasi penimbangan. Kader dengan tingkat pendidikannya SMP ke atas memiliki tingkat akurasi baik yaitu sebesar $36.6 \%$ dibandingkan dengan pendidikan SD yang hanya $20 \%$. Hal tersebut terjadi karena tingkat pendidikan mempengaruhi kemampuan menerima informasi, orang dengan tingkat pendidikan rendah cenderung sulit menerima suatu hal baru, sebaliknya seseorang dengan tingkat pendidikan tinggi akan lebih mudah menerima hal baru dan cenderung lebih terbuka (Rahardjo, 2011).

Meskipun penyuluhan dilakukan daring, para kader menunjukkan antusiasnya dalam mengikuti kegiatan webinar. Peserta hadir tepat waktu, menjawab pertanyaan secara interaktif di tengah-tengah penyampaian materi dan memberikan pertanyaan serta berdiskusi di sesi tanya jawab seperti yang terlihat di Gambar 2. Pertanyaan diberikan kader melalu beberapa cara, pertama dengan mengungkapkan pertanyaan dengan terlebih dahulu menghidupkan mikrofon pada zoom. Kedua dengan menuliskan pertanyaan di sela-sela pemberian materi, atau akhir pemberian materi melalui Whatssapp group maupun di kolom komentar di zoom. Pada setiap pertemuan, kader memberikan sekitar 10 pertanyaan yang menunjukkan bahwa peserta menyimak dengan seksama materi yang diberikan. Peserta juga mengelaborasikan kondisi aktual di Posyandu dalam pertanyaan yang diajukan.

Berdasarkan hasil evaluasi melalui nilai pre-dan post-test, proporsi kader yang dikategorikan memiliki pengetahuan yang baik meningkat jumlahnya dari $54.5 \%$ sebelum webinar menjadi $84.8 \%$ (Tabel 2). Nilai rata-rata pengetahuan kader saat pretest adalah 65 yang meningkat setelah mengikuti webinar menjadi 85 (Tabel 3), ini merupakan hasil yang diharapkan sesuai dengan tujuan dari webinar.

Nilai pengetahuan peserta pun terlihat sangat berbeda nyata jika diuji secara statistik $(p<0.05)$. Capaian ini menunjukkan bahwa penyuluhan dengan webinar dapat memberikan efek yang serupa dalam meningatkan pengetahuan kader, seperti halnya penyuluhan secara tatap muka (Hidayat et al., 2019). Peningkatan pengetahuan akan membuat kader lebih kompeten dan percaya diri dalam 
menjalankan kegiatan posyandu dan mengedukasi masyarakat. Peserta juga memahami bahwa meskipun dalam masa peralihan PSBB, penyuluhan dan pemantauan bayi, balita dan ibu hamil bisa dilakukan dengan menggunakan gawai pintar peserta.

Proporsi kader yang memiliki motivasi sangat baik meningkat dari $51.5 \%$ menjadi $84.8 \%$ setelah webinar. Motivasi dari kader yang baik menentukan kinerja peserta yang berdampak pada tingkat partisipasi ibu dan balita (Husniyawati \& Wulandari, 2016). Menjaga dan meningkatkan motivasi peserta saat pandemi COVID-19 sangat penting dilakukan. Beberapa kader mengeluhkan keterbatasan peserta dalam melaksanakan Posyandu. Melalui kegiatan webinar ini peserta mendapatkan informasi baru mengenai kegiatan yang mungkin dilakukan kader ketika terjadi kasus COVID-19 atau masalah gizi buruk terjadi. Terutama siapa yang harus peserta hubungi untuk merujuk pasien. Melalui kegiatan ini, kader teringat kembali tahapan yang harus peserta lakukan dalam penyelenggaraan Posyandu.

Motivasi kader yang meningkat dapat membuat kegiatan Posyandu berjalan lebih baik, tingkat partisipasi masyarakat tinggi dan peningkatan deteksi dini masalah kesehatan. Sebaliknya jika motivasi kader rendah maka kegiatan Posyandu tidak akan berjalan dengan baik, partisipasi masyarakat kurang, dan sulit melakukan perubahan perilaku masyarakat. Selama pandemi COVID-19 ini, kegiatan posyandu tidak bisa dilakukan seperti biasanya, adanya kader dapat memastikan tumbuh kembang balita, megedukasi masyarakat mengenai pencegahan COVID-19. Kegiatan serupa untuk menggencarkan pesan pencegahan COVID-19, penyuluhan berbasis video juga telah dilaksanakan kepada remaja (Khodijah, dkk 2021).

Setelah webinar, peserta kemudian dapat menjelaskan kembali dengan menyebutkan bahwa COVID-19 dapat menyebar melalui droplet, penularan dapat terjadi ketika seseorang berada pada jarak dekat (dalam 1 meter) dengan sesorang yang memiliki gejala pernapasan (misalnya, batuk atau bersin) sehingga droplet berisiko mengenai mukosa (mulut dan hidung) atau konjungtiva (mata).

Tabel 2. Pengetahuan dan Motivasi Kader

Posyandu Sebelum dan Sesudah Webinar

\begin{tabular}{cccc}
\hline Variabel & Pre & Post & P-value \\
\hline Pengetahuan & 65 & 85 & $0.000^{*}$ \\
& $(40-95)$ & $(70-90)$ & \\
Motivasi & 90 & 100 & $0.028^{*}$ \\
& $(70-100)$ & $(70-100)$ & \\
\hline
\end{tabular}

Tabel 3. Perbedaan Pengetahuan dan Motivasi Kader Sebelum dan Sesudah Webinar

\begin{tabular}{lc}
\hline \multicolumn{1}{c}{ Variabel } & $\mathrm{n}(\%)$ \\
\hline Pengetahuan Kader & \\
Nilai Pre Test & \\
Kurang & $15(45.5)$ \\
Baik & $18(54.5)$ \\
Nilai Post Test & $5(15.2)$ \\
Kurang & $28(84.8)$ \\
Baik & \\
Motivasi Kader & \\
Nilai Pre Test & $2(6.1)$ \\
Cukup Baik & $14(42.4)$ \\
Baik & $17(51.5)$ \\
Sangat baik & \\
Nilai Post Test & $1(3)$ \\
Cukup Baik & $4(12.1)$ \\
Baik & $28(84.8)$ \\
Sangat baik &
\end{tabular}

Selain itu, perlu dilakukan modifikasi dalam pelaksanaan seperti yang disampaikan di materi webinar misalnya, pendataan dilakukan secara online selama pandemi, bisa melalui grup Whatsapp. Manajemen data juga dapat dilakukan dengan Microsoft Excel yang dapat diakses melalui gawai pintar (smartphone) sehingga data terdokumentasikan dengan baik. Setelah acara berakhir, masing-masing kader yang berpartisipasi mendapatkan sertifikat dari pihak penyelenggara yang diberikan secara langsung oleh petugas Puskesmas (Gambar 3). 


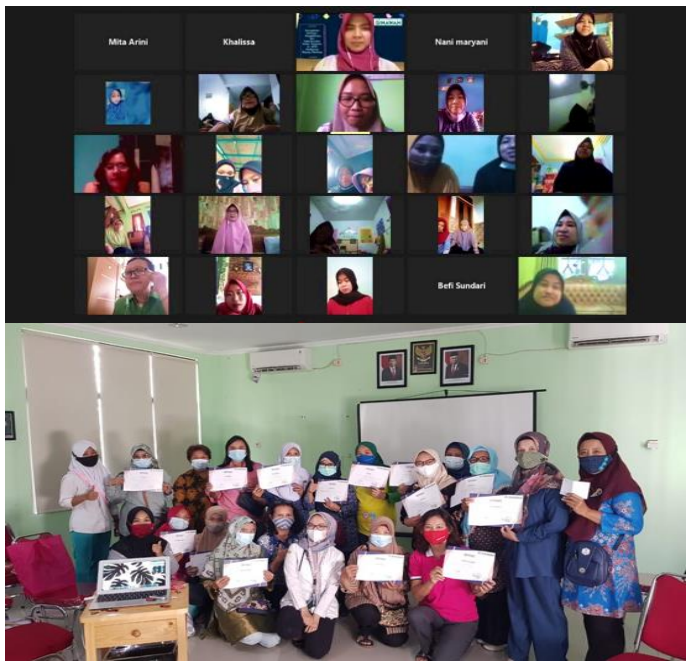

Gambar 2. Dokumentasi pemberian sertifikat kepada peserta

\section{KESIMPULAN DAN SARAN}

\section{Kesimpulan}

Mayoritas responden berada di rentang usia 31 - 45 tahun dengan tingkat pendidikan SMA. Edukasi kepada kader Posyandu dengan metode webinar dapat meningkatkan pengetahuan dan motivasi kader secara signifikan. Webinar dapat menjadi cara yang potensial dalam penyegaran dan edukasi kader Posyandu selama pandemi. Namun ada beberapa hal yang perlu digarisbawahi sebagai tantangan dalam penyelenggaraan webinar ini. Tantangan tersebut antara lain: kader harus memiliki gawai pintar, kader di perkotaan kemungkinan lebih mudah menggunakan metode ini dibandingan di pedesaan. Tantangan lainnya yaitu kestabilan jaringan yang menentukan kualitas penyampaian materi dan sesi diskusi.

\section{Saran}

Pengabdian lebih lanjut dapat dilakukan dengan materi yang lebih dalam. Jangka waktu pelaksanaan pengabdian masyarakat agar dapat diperpanjang mengingat sulitnya transfer ketrampilan dalam waktu yang relatif sempit.

\section{UCAPAN TERIMA KASIH}

Pelaksana mengucapkan terima kasih kepada Fakultas Kesehatan Masyarakat Universitas Binawan yang telah memberikan dana untuk pelaksanaan kegiatan pengabdian masyarakat ini. Terima kasih juga disampaikan kepada Puskesmas Bojong Menteng atas pemberian izin dan juga bantuan dalam persiapan dan pelaksanaan kegiatan pengabdian masyarakat. Ucapan erima kasih juga disampaikan kepada para Kader Posyandu selaku sasaran yang sudah bersedia menjadi peserta dan turut berpartisipasi dengan baik pada kegiatan pengabdian ini, serta semua pihak yang telah membantu dan memberikan dukungan baik secara langsung maupun tidak langsung hingga terselesaikannya kegiatan ini.

\section{DAFTAR PUSTAKA}

Dinas Kesehatan Kota Bekasi. 2021. Data Sebaran Covid-19 Kota Bekasi. https://corona.bekasikota.go.id/

Dinkes Kota Bekasi. 2014. Profil Kesehatan Kota Bekasi Tahun 2014. Profil Kesehatan Kota Bekasi Tahun 2014 , 304. http://www.depkes.go.id/resources/d ownload/profil/PROFIL_KAB_KO TA_2014/3275_Jabar_Kota_Bekasi 2014.pdf

Fore, H. H., Dongyu, Q., Beasley, D. M., \& Ghebreyesus, T. A. 2020. Child malnutrition and COVID-19: the time to act is now. The Lancet, 396(10250), 517-518. https://doi.org/10.1016/S01406736(20)31648-2

Ghozali M. T., Hadning I., Winata A. 2020. Pelatihan Pembuatan Sistem Informasi Kesehatan Elektronik Untuk Kader Kesehatan Desa Tijayan Manisrenggo Jawa Tengah. Aksiologiya: Jurnal Pengabdian Kepada Masyarakat.

Hardiyanti, R., Idrus, J., Dudung, A. 2018. Hubungan Lama Kerja Menjadi 
Kader, Pengetahuan, Pendidikan, Pelatihan, dengan Presisi dan Akurasi Hasil Penimbangan Berat Badan Balita Oleh Kader Posyandu. Jurnal AcTion, 3 (1), pp. 74-81.

Hidayat, W., Nanan, N., Indah, S.W. 2019. Gambaran Pre dan Post Test Kegiatan Penyuluhan Kesehatan Terhadap Kader Posyandu di Puskesmas Babatan Bandung. Dharmakarya: Jurnal Aplikasi Ipteks untuk Masyarakat, 8 (4), pp. 225-226

Husniyawati, Y. R., \& Wulandari, R. D. 2016. Analisis Motivasi Terhadap Kinerja Kader Posyandu Berdasarkan Teori Victor Vroom. Jurnal Administrasi Kesehatan Indonesia, 4(2), pp. 126. https://doi.org/10.20473/jaki.v4i2.20 16.126-135

Kemenkes RI. 2014. Kurikulum dan Modul Pelatihan Kader Posyandu.

Kementerian Kesehatan RI Pusat Promosi Kesehatan. 2012. Ayo ke Posyandu Setiap Bulan: Posyandu Menjaga Anak dan Ibu Tetap Sehat. In Transfusion Medicine and Hemotherapy. https://doi.org/10.1159/000317898

Kementerian Kesehatan. 2018. RISKESDAS 2018. Kementerian Kesehatan RI. https://doi.org/978-602-8937-24-5

Komite Penanganan COVID-19 dan Pemulihan Ekonomi Naisonal. 2021. Data sebaran COVID-19 secara Global dan Indonesia. https://covid19.go.id/.

Khodijah, K., Itsna, I. N., \& Oktiawati, A. 2021. Edukasi Pencegahan Covid19 Berbasis Video bagi Remaja di Rumah Yatim Anak Sholeh. Jurnal Abdimas Kesehatan (JAK), 3 (1), pp. 10-17.

Kusudaryati, D. P. D., Untari, I., Prananingrum, R. 2017. Peningkatan pengetahuan kader posyandu tentang balita melalui pemberian pendidikan dan buku gizi. Prosiding University Research Colloquium, pp. 25 - 29.

Lubis, Z. 2015. Pengetahuan dan Tindakan Kader Posyandu dalam Pemantauan Pertumbuhan Anak Balita. Jurnal Kesehatan Masyarakat, 11(1), pp.65.https://doi.org/10.15294/kema s.v11i1.3473

Presiden Republik Indonesia. 2020. Peraturan Pemerintah NO. 21 Tahun 2020 tentang Pembatasan Sosial Berskala Besar Dalam Rangka Percepatan Penanganan Coronavirus Disease 2019/COVID19. 2019(022868), pp. 8.

Rahardjo, S., Erna, K. 2011. Hubungan Tingkat Pendidikan dan Pengetahuan dengan Perilaku Keluarga Sadar Gizi (Kadarzi) Pada Masyarakat Perkotaan dan Pedesaan di Kabupaten Banyumas.

Solehati, T., Sari, C. W. M., Lukman, M., \& Kosasih, C. E. 2018. Pengaruh Pendidikan Kesehatan Terhadap Pengetahuan Deteksi Dini dan Pencegahan Anemia Dalam Upaya Menurunkan Aki Pada Kader Posyandu. Jurnal Keperawatan Komprehensif, 4(1), pp. 7. https://doi.org/10.33755/jkk.v4i1.75.

Susanto A. 2017. Peran Kader Posyandu Sebagai Agen Perubahan Perilaku Pada Ibu Hamil Dalam Upaya Menekan Angka Kematian Ibu dan Bayi. 2nd Seminar Nasional IPTEK Terapan (SENIT) 2017, pp. 189193.

WHO. 2020. Coronavirus disease 2019 (covid-19). In Situation Report-94. https://doi.org/10.6314/JIMT.20200 4_31(2).01

Yang, H., Wang, C., \& Poon, L. C. 2020. Novel coronavirus infection and pregnancy. Ultrasound in Obstetrics and Gynecology, 55(4), pp. 435437.https://doi.org/10.1002/uog.220 06 